\title{
Abundance of Somatostatin Cells in the Human Neonatal Pancreas
}

\author{
J. Rahier, J. Wallon, and J. C. Henquin \\ Department of Pathology, School of Medicine, University of Louvain, Brussels, Belgium
}

\begin{abstract}
Summary. Pancreatic somatostatin cells have been studied in human neonates and adults using an immunoperoxidase technique. Their volume density in the head, isthmus, corpus and tail of the gland has been estimated by morphometry. Somatostatin cells were about 20 times more frequent in the neonate ( $5 \%$ of all pancreatic cells) than in the adult $(0.23 \%)$. Their distribution between the different zones of the pancreas showed few differences except for the lobe of the head rich in PP cells, where the volume density of somatostatin cells was $40 \%$ lower.
\end{abstract}

Key words: Somatostatin cells, human pancreas, neonates, immunocytochemistry.

The presence of somatostatin in the rat and human endocrine pancreas has been demonstrated by immunocytochemical techniques $[5,11,17]$ and confirmed by radioimmunoassay $[2,16]$. Ultrastructural studies have subsequently identified the somatostatin containing cells as D cells lying mainly within the islets $[8,14]$.

Although the high proportion of endocrine tissue in the pancreas of infants has long been recognized [13], little attention has been paid, so far, to the contribution of somatostatin cells in this tissue. Two qualitative studies have demonstrated the presence of somatostatin cells in the human fetus $[1,6]$. With ultrastructural and histochemical techniques $[4,10]$, it has been shown that the islets of neonates or young infants contain a high proportion of non-insulin and non-glucagon cells, most likely corresponding to somatostatin cells. This has been recently confirmed [15] with an immunofluorescence method. This report is a quantitative study of pancreatic somatostatin cells in neonates and in adults.

\section{Materials and Methods}

Pancreases were obtained, at autopsy, from 5 neonates born to non-diabetic mothers and from 4 adults without diabetes. The neonates ranged in age from 8 to 15 days and in weight from 2.4 to $3.1 \mathrm{~kg}$. The pancreas weight varied from 2.73 to $2.99 \mathrm{~g}$. Four of the neonates died as a result of cardiac malformation; the cause of death was uncertain for the fifth neonate. The adults were aged 31 , 46,60 and 66 with bodyweights of $45-55 \mathrm{~kg}$; the weight of the pancreas was $80,75,160$ and $88 \mathrm{~g}$. The causes of death were Von Recklinghausen disease, Crohn's disease, renal failure and cardiac failure. The pancreas was removed within $6 \mathrm{~h}$ after death and carefully dissected from adjacent lymph nodes, fat and vessels. Slices cut through the head, isthmus, corpus and tail were fixed for $24 \mathrm{~h}$ in Bouin-Allen's solution and embedded in paraffin.

Sections of $5 \mu \mathrm{m}$ thickness were mounted on glass slides with aqueous gelatin, dried for $12 \mathrm{~h}$ at $60^{\circ} \mathrm{C}$ and processed by the peroxidase antiperoxidase technique of Sternberger [19, 20]. Rabbit anti-somatostatin serum (a gift of Prof. W. Gepts, Brussels) and rabbit anti-bovine pancreatic polypeptide serum (a gift of Prof. R. E. Chance, Eli Lilly, Indianapolis) were used at dilutions of $1 / 20,000$ and $1 / 40,000$, respectively. Rabbit antiperoxidase bound to horseradish peroxidase (Prof. W. Gepts) was used at a dilution of $1 / 30$. To reveal the peroxidase, the sections were treated with a

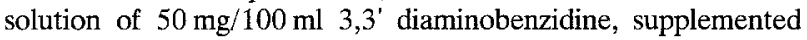
with $40 \mu \mathrm{l}$ hydrogen peroxide $(30 \%)$ per $100 \mathrm{ml}$ [9]. The specificity of the method was assessed by control studies using antisomatostatin serum absorbed overnight at $4^{\circ} \mathrm{C}$ with an excess $(20 \mu \mathrm{g} / \mathrm{ml})$ of cyclic somatostatin (Bachem), pork MC insulin, pork MC glucagon or bovine pancreatic polypeptide (bPP).

In the slice cut through the head, distinction was made between the lobe rich in pancreatic polypeptide (PP) cells [18] and the rest of the gland. A section, adjacent to that processed for somatostatin cells, was treated with anti bPP serum to delineate the limits of the lobe rich in PP cells. The volume density of somatostatin cells in the whole pancreas was estimated by the point counting method of Chalkley [3], using a 42 point lattice at a linear magnification of $800 \times$. The percentage of $D$ cell tissue was obtained by the ratio of the number of hits on D cells to the number of hits on other epithelial cells (excluding thus mesenchymal tissue). In one complete section from the 4 slices of pancreas, one field out of 5 , automatically selected by the Eltinor system (Jenoptik, Jena), was systematically examined. It has been reported [21] that the mesenchymal tissue is particularly abundant in the newborn pancreas. Therefore, its volume density was determined by the same technique of point counting on sections stained with hemalun-eosinsafran. This permits correction of the weight of the whole pancreas 

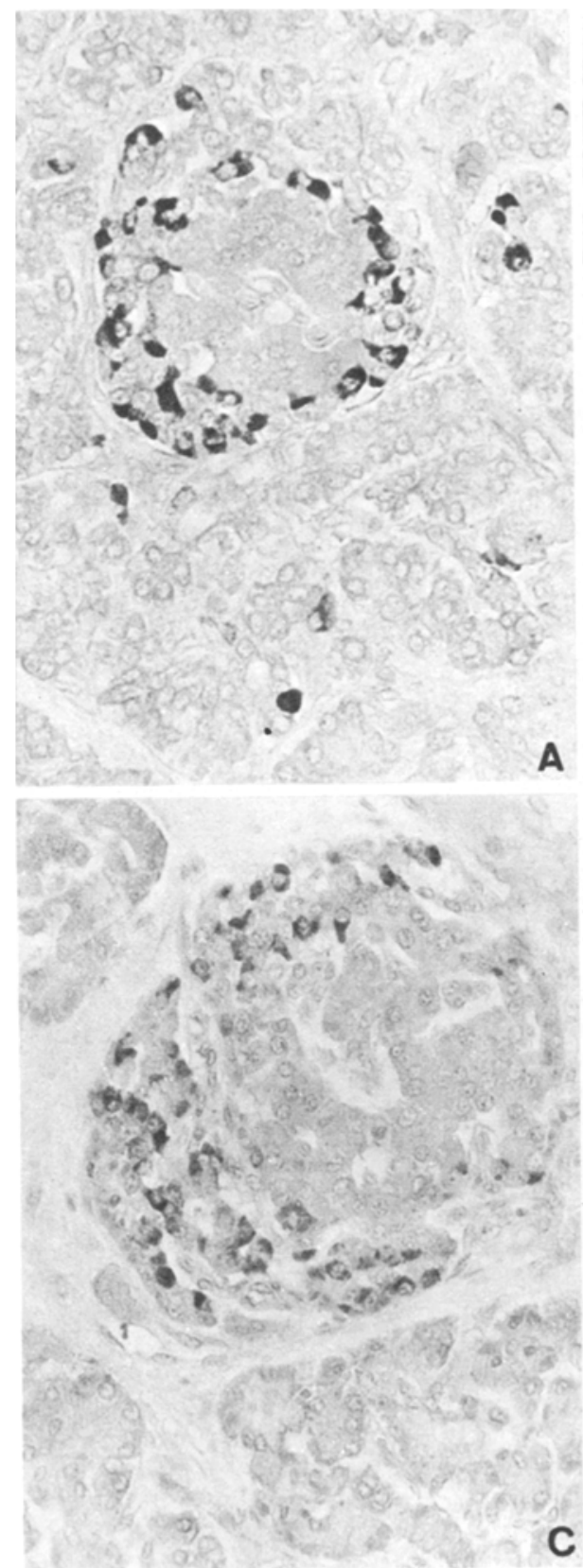
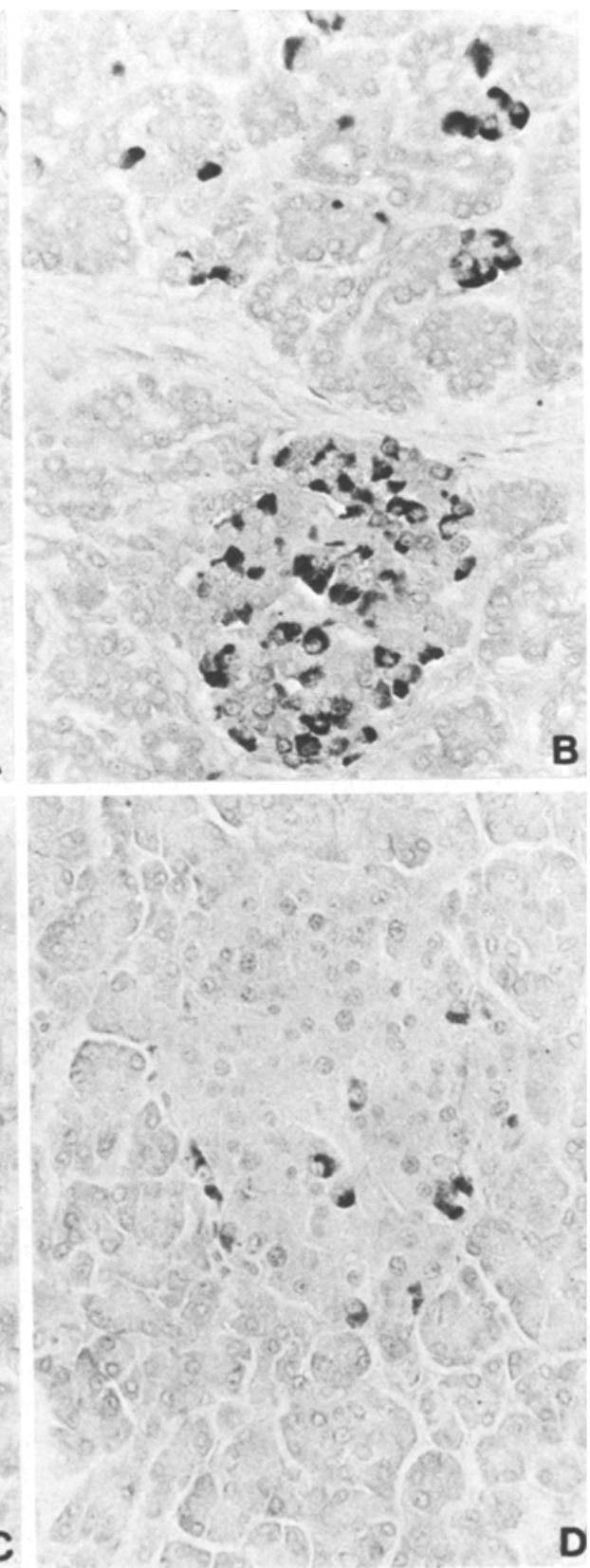

Fig. 1A-D. Human pancreatic tissue processed by the peroxidase antiperoxidase technique with anti-somatostatin serum to show the different patterns of distribution of somatostatin cells. A-C Neonatal pancreas. Numerous somatostatin cells are located at the periphery of the islets A, are scattered throughout the islets $\mathbf{B}$ or concentrated in a crescent zone at one pole $\mathbf{C}$. Pattern $\mathrm{A}$ is by far the most frequent and pattern $\mathrm{C}$ is rare. Isolated somatostatin cells are also frequent in the exocrine tissue. D Adult pancreas. $\times 300$

Table 1. Volume density of somatostatin cells in the neonate and adult pancreas (\%)

\begin{tabular}{llllll}
\hline & Head & Isthmus & Corpus & Tail \\
\cline { 2 - 6 } & $\begin{array}{l}\text { Zone rich in } \\
\text { PP cells }\end{array}$ & $\begin{array}{l}\text { Zone poor in } \\
\text { PP cells }\end{array}$ & & & \\
\hline Neonates & $2.95 \pm 2.14^{\mathrm{a}}$ & $4.77 \pm 1.44$ & $4.65 \pm 1.19$ & $4.96 \pm 2.44$ & $7.48 \pm 4.63$ \\
Adults & $0.15 \pm 0.09$ & $0.22 \pm 0.09$ & $0.22 \pm 0.10$ & $0.29 \pm 0.10$ & $0.25 \pm 0.09$ \\
\hline
\end{tabular}

Values are means $\pm \mathrm{SD}$.

a Significantly lower $(\mathrm{P}<0.05)$ than in the other zones 
to be made for the contribution of mesenchymal tissue and thus the weight of epithelial tissue to be obtained. The absolute mass of somatostatin cells can then be evaluated by multiplying the mean volume density of somatostatin cells by the mean weight of epithelial cells.

All results are presented as mean $\pm \mathrm{SD}$ and the differences between means was assessed by the Wilcoxon rank-sum test.

\section{Results}

Numerous cells displaying immunoreactivity with the anti-somatostatin serum were seen in the pancreas of all neonates. Most of these cells $(86 \pm 2 \%)$ were located in islets, where they frequently formed a peripheral network; sometimes they were more diffusely distributed and less frequently they were concentrated in a crescent zone at one pole of the islets (Fig. $1 \mathrm{~A}-\mathrm{C}$ ). They appeared ovoid or triangular in form with occasional thin processes intermingled with other endocrine cells. As shown in Table 1, the volume density of somatostatin-containing cells varied only slightly between the different regions of the pancreas, except in the lobe rich in PP cells where it was approximately $40 \%$ lower than in the rest of the gland $(\mathrm{P}<0.05)$.

In the adult pancreas, cells reacting with the antisomatostatin serum were also preferentially $(90 \pm$ $5 \%$ ) located in islets, at the periphery or along small capillaries (Fig. 1D). Their frequency was, however, much lower than in the neonatal pancreas. Table 1 gives a quantitative evaluation of this difference. In all zones of the pancreas, the volume density of somatostatin cells was approximately 20 times lower in the adult than in the neonate. The distribution of these cells between the different regions of the gland was similar to that found in the newborn.

In the present series of neonate and adult pancreases, we have found a volume density of mesenchymal tissue of $26.8 \pm 5.5 \%$ and $15.8 \pm 8.2 \%$, respectively.

\section{Discussion}

Simple examination of pancreatic sections stained for somatostatin reveals a striking difference in the frequency of cells reacting with the anti-somatostatin serum in the adult and in the neonate. Morphometrical analysis shows that the volume density of pancreatic somatostatin cells is about 20 times higher at birth. This measurement of the volume density of somatostatin cells was made relative to the volume of all epithelial cells in the pancreas. To evaluate the total mass of D cells, we have thus corrected the weight of the gland for the contribution of the mesen- chymal tissue. However, this evaluation still meets with the problem of a non-homogenous distribution of somatostatin cells between the different zones. By taking the mean volume density of somatostatin cells in the four regions and the mean weight of epithelial tissue, we have estimated that the newborn pancreas contains about $100 \mathrm{mg}$ and the adult pancreas about $190 \mathrm{mg}$ somatostatin cells. The presence of such an important mass of somatostatin cells at birth may suggest that the hormone plays a particular, and so far unrecognized, role during fetal or early extrauterine life. Whether this role includes a paracrine control of the development or of the functional maturation of insulin and glucagon cells remains to be evaluated.

Both in the neonate and in the adult pancreas, the relative volume of somatostatin cells was $40 \%$ lower in the lobe rich in PP cells than in the rest of the gland. This emphasizes the different composition of the endocrine tissue located in the pancreatic parenchyma, thought to derive from the ventral and dorsal primordia $[7,12,18]$.

Acknowledgements. We are grateful to Mrs S. Vandeputte-Loozen for technical assistance and Miss M. Nenquin for editorial help. J. C. H. is "Chargé de Recherches" of the FNRS, Brussels.

\section{References}

1. Alumets J, Sundler F, Håkanson R (1977) Distribution, ontogeny and ultrastruture of somatostatin immunoreactive cells in the pancreas and gut. Cell Tissue Res 185: 465-479

2. Arimura A, Sato H, Dupont A, Nishi N, Schally A V (1975) Somatostatin: Abundance of immunoreactive hormone in rat stomach and pancreas. Science 189: 1007-1009

3. Chalkley HW (1943) Method for the quantitative morphologic analysis of tissues. J Natl Cancer Inst 4: 47-53

4. Deconinck, JF, Van Assche FA, Potvliege P R, Gepts W (1972) The ultrastructure of the human pancreatic islets. II. The islets of neonates. Diabetologia 8: $326-333$

5. Dubois MP (1975) Presence of immunoreactive somatostatin in discrete cells of the endocrine pancreas. Proc Natl Acad Sci USA 72: 1340-1343

6. Dubois PM, Paulin C, Assan R, Dubois MP (1975) Evidence for immunoreactive somatostatin in the endocrine cells of human foetal pancreas. Nature 256: 731-732

7. Gersell D J, Gingerich RL, Greider, MH (1979) Regional distribution and concentration of pancreatic polypeptide in the human and canine pancreas. Diabetes 22: 11-15

8. Goldsmith PC, Rose J C, Arimura A, Ganong W F (1975) Ultrastructural localization of somatostatin in pancreatic islets of the rat. Endocrinology 97: 1061-1064

9. Graham RC, Karnovsky M J (1966) The early stages of absorption of injected horseradish peroxidase in the proximal tubules of mouse kidney: Ultrastructural cytochemistry by a new technique. J Histochem Cytochem 14: 291-302

10. Klöppel G, Altenähr E, Reichel W, Willig R, Freytag G (1974) Morphometric and ultrastructural studies in an infant with leucine sensitive hypoglycemia, hyperinsulinism and islet hyperplasia. Diabetologia 10: 245-252 
11. Luft R, Efendic S, Hökfelt T, Johansson O, Arimura A (1974) Immunohistochemical evidence for the localization of somatostatin-like immunoreactivity in a cell population of the pancreatic islets. Med Biol 52: 428-430

12. Malaisse-Lagae F, Orci L, Perrelet A (1979) Anatomic and hormonal markers for the ventral primordium in the human pancreas? (Letter) N Engl J Med 300: 436

13. Ogilvie RF (1937) A quantitative estimation of the pancreatic islet tissue. Q J Med 6: 287-300

14. Orci L, Baetens D, Dubois MP, Rufener C (1975) Evidence for the D-cell of the pancreas secreting somatostatin. Horm Metab Res 7: 400-405

15. Orci L, Stefan Y, Malaisse-Lagae F, Perrelet A (1979) Instability of pancreatic endocrine cell populations throughout life. (Letter) Lancet I: 615

16. Patel YC, Weir GC (1976) Increased somatostatin content of islets from streptozotocin-diabetic rats. Clin Endocrinol (Oxf) 5: 191-194

17. Polak J M, Pearse A GE, Grimelius L, Bloom S R, Arimura A (1975) Growth hormone release-inhibiting hormone in gastrointestinal and pancreatic D cells. Lancet I: $1220-1222$

18. Rahier J, Wallon J, Gepts W, Haot J (1979) Localization of pancreatic polypeptide cells in a limited lobe of the human neonate pancreas: remnant of the ventral primordium? Cell Tissue Res 200: 359-366

19. Sternberger LR, Hardy PH, Cuculis J J, Meyer HG (1970) The unlabeled antibody enzyme method of immunohistochemistry. Preparation and properties of soluble antigen antibody complex (horseradish peroxidase - antihorseradish peroxidase) and its use in the identification of spirochetes. J Histochem Cytochem 18: 315-333

20. Sternberger LR (1974) Immunocytochemistry. Prentice Hall, Inc., Englewood Cliffs, New Jersey

21. Van Assche F A (1970) The fetal endocrine pancreas. A quantitative morphological approach. Thesis. Leuven, Katholieke Universiteit

Received: August 29, 1979 , and in revised form: November 13, 1979

Dr. J. Rahier

Department of Pathology

University Hospital St. Luc

Av. Hippocrate, 10

B-1200 Brussels

Belgium 